\title{
The Effectiveness of Probiotics against Viral Infections: A Rapid Review with Focus on SARS-CoV-2 Infection
}

\author{
Jehan Abdul-Sattar Salman ${ }^{1}$, Nibras Nazar Mahmood ${ }^{1}$, Ban Oday Abdulsattar ${ }^{1}$, Hussein Adil Abid ${ }^{2 *}$ \\ ${ }^{1}$ Department of Biology, College of Science, Mustansiriyah University, Baghdad, Iraq; ${ }^{2}$ Department of Medical Laboratory \\ Technology, Technical Institute of Baquba, Middle Technical University, Baqubah, 32001, Iraq
}

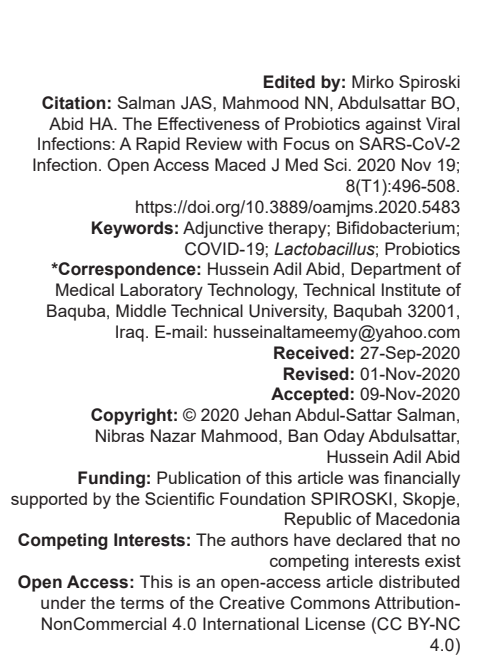

\section{Abstract}

Viral infections have gained great attention following the rapid emergence of the severe acute respiratory syndrome coronavirus 2 (SARS-CoV-2) pandemic around the globe. Even with the continuous research on developing vaccines and antiviral agents against various viral infections, no specific treatment or vaccine has been approved for many enteric or respiratory viral infections; in addition, the efficiency of currently available treatments is still limited. One of the most reliable and recommended strategies to control viral infections is prevention. Recently, intense studies are focusing on a promising approach for treating/preventing various viral infections using probiotics. As per the World Health Organization (WHO), probiotics can be defined as "live microorganisms which, when administered in adequate amount, confer a health benefit to the host." The use of probiotics is a simple, cost-effective, and safe strategy to prevent viral infections, specifically; respiratory tract and intestinal ones, by different means such as stimulating the host's immune response or modulating gut microbiota. In this rapid review, we emphasize the protective effects of probiotics against viral infections and proposed mechanisms for protection that might offer a novel and cost-effective treatment against current and newly discovered viruses like SARS-CoV-2.

\section{Introduction}

The first scientific evidence regarding probiotics was made by Nobel laureate Metchnikoff, who sensed that the intake of non-pathogenic bacteria with yogurt had a positive influence on endogenous bacterial flora and gastrointestinal tract's functionality [1]. The term "probiotics" was first used in 1953 by Werner Kollath to describe inorganic and organic supplements of several foods used to improve the health of malnutrition patients [2]. In 1965, Lilly and Stillwell used the term "probiotics" to describe microorganisms that promote other microbial growth [3]. Later, FAO/WHO has defined probiotics as "live microorganisms which, when administered in adequate amount, confer a health benefit to the host [4]." Figure 1 illustrates some beneficial effects of probiotics on human health.

Tobeclassified as a probiotic, the microorganism should have certain characteristics, such as having a human origin source, being non-pathogenic, being resistant to the intestinal environment, and having a beneficial effect on the immune system. The majority of the probiotic microorganisms are "generally recognized as safe, GRAS" [6]. Most lactic acid bacteria (LAB) and bifidobacteria have been described as probiotics [7], [8]. However, the most common probiotic microorganisms are listed in Table 1.

In addition to their important biological activities, the probiotics were previously defined to have antiviral activities. Ang et al. [38] have confirmed in this context that Lactobacillus reuteri is capable of protecting human skeletal muscles and colonic cell line against Coxsackievirus $A$ and Enterovirus 71 infections. In addition, Galán et al. [39] have proven the antiviral activity of Lactobacillus casei and Bifidobacterium adolescentis against rotavirus infection. Moreover, Bacillus subtilis anti-influenza activity and Lactobacillus gasseri anti-respiratory sentential virus potential have also been proved by Starosila et al. and Eguchi et al., respectively. However, many other studies are being conducted to investigate the efficacy of probiotics against certain viral infections.

At the end of the year 2019, an etiological agent responsible for the outbreak of viral pneumonia was detected in Wuhan, Hubei Province, China, and spread rapidly around the world. Then, this new virus was named by the International Committee on 


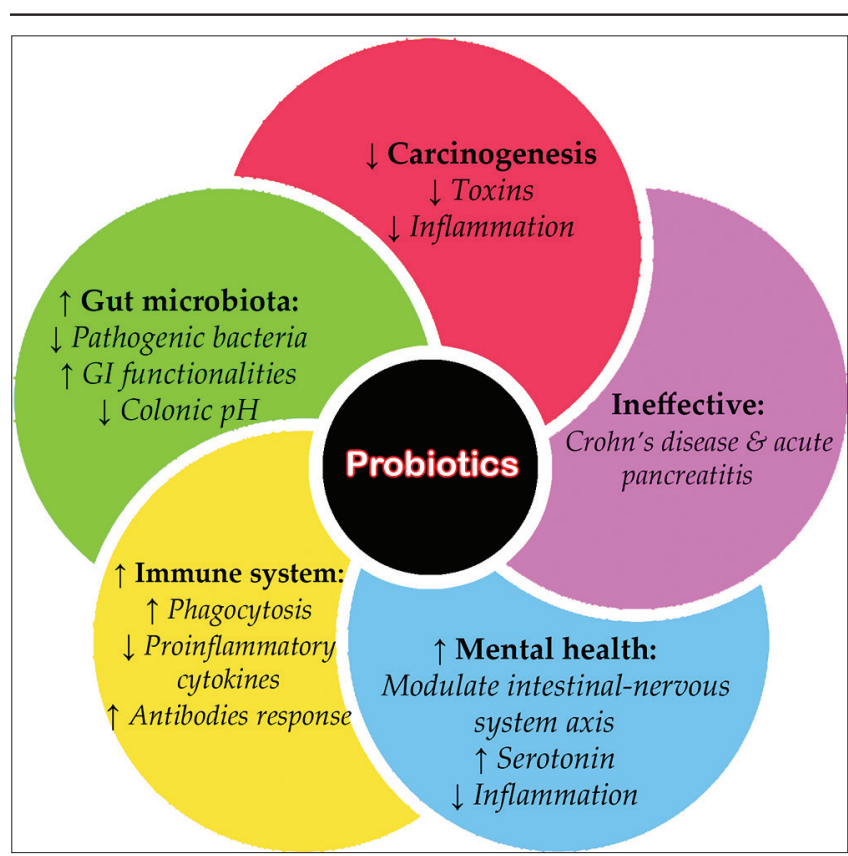

Figure 1: Probiotics' beneficial properties to human health [5]

Taxonomy of Viruses as severe acute respiratory syndrome coronavirus 2 (SARS-CoV-2), causing coronavirus disease 19 (COVID-19) [42]. SARSCoV-2 belongs to the Orthocoronavirinae subfamily of the Coronaviridae family in the order Nidovirales. Coronaviruses named after the distribution of crownlike spikes on the outer surface of the virus particle. In addition, the nucleic material of these viruses is a singlestranded, positive-sensing RNA (+ssRNA) [43], [44].

Table 1: Some major probiotic microorganisms

\begin{tabular}{|c|c|c|c|}
\hline & Genera & Probiotic strains & References \\
\hline \multirow[t]{10}{*}{ Bacteria } & Lactobacillus & $\begin{array}{l}\text { L. acidophilus } \\
\text { L. amylovorus } \\
\text { L. brevis } \\
\text { L. casei } \\
\text { L. crispatus } \\
\text { L. curvatus } \\
\text { L. delbrueckii subsp. } \\
\text { bulgaricus } \\
\text { L. fermentum } \\
\text { L. gallinarum } \\
\text { L. gasseri } \\
\text { L. johnsonii } \\
\text { L. paracasei } \\
\text { L. plantarum } \\
\text { L. reuteri } \\
\text { L. rhamnosus } \\
\text { L. salivarius }\end{array}$ & $\begin{array}{l}\text { [9], [10], [11], [12], [13], } \\
{[14],[15],[16]}\end{array}$ \\
\hline & Bifidobacterium & $\begin{array}{l}\text { B. adolescentis } \\
\text { B. animalis } \\
\text { B. bifidum } \\
\text { B. breve } \\
\text { B. infantis } \\
\text { B. longum } \\
\text { B. thermophilum }\end{array}$ & $\begin{array}{l}\text { [17], [18], [19], [20], [21], } \\
\text { [22] }\end{array}$ \\
\hline & Enterococcus & $\begin{array}{l}\text { E. faecalis } \\
\text { E. faecium }\end{array}$ & [23], [24] \\
\hline & Lactococcus & L. lactis & [25], [26] \\
\hline & Leuconostoc & L. mesenteroides & {$[27]$} \\
\hline & Pediococcus & P. acidilactici & {$[28]$} \\
\hline & Sporolactobacillus & S. inulinus & [29] \\
\hline & Streptococcus & S. thermophilus & [30] \\
\hline & Bacillus & $\begin{array}{l}\text { B. cereus } \\
\text { B. clausii } \\
\text { B. pumilus } \\
\text { B. subtilis }\end{array}$ & [31], [32] \\
\hline & $\begin{array}{l}\text { Escherichia } \\
\text { Propionibacterium }\end{array}$ & $\begin{array}{l}\text { E. coli Nissle } 1917 \\
\text { P. freudenreichii }\end{array}$ & $\begin{array}{l}{[33],[34]} \\
{[35]}\end{array}$ \\
\hline Yeast & Saccharomyces & $\begin{array}{l}\text { S. cerevisiae } \\
\text { S. boulardii }\end{array}$ & [36], [37] \\
\hline
\end{tabular}

SARS-CoV-2 genome encodes 27 proteins, including capsid (S) and envelope (N). The S-protein binds the angiotensin-converting enzyme 2 (ACE-2) receptor, which is widespread in many human tissues (including the lungs and gut) and can indirectly modulate nutrient transport to the intestine, reduce the bioavailability of vitamins and amino acids essential for the production of antibodies and immune regulation in general [45]. Clinically, SARS-CoV-2 is reported to cause respiratory and gastrointestinal tract symptoms. Although scientists around the world work hard and respond rapidly in developing a new vaccine or antiviral medication for SARS-2, no COVID-19 vaccine or new effective antiviral medicines are approved yet. In such circumstances, the most reliable and recommended strategy to control viral infections is prevention.

In this review, we sought to elucidate the mechanisms through which the probiotics exert their antiviral and preventive potential as well as the possibility of using them to improve the COVID-19 patient's health.

\section{Possible Antiviral Mechanisms of Probiotics}

The probiotics' antiviral effects may exert by several mechanisms, including the production of antiviral inhibitory substances, direct interaction with viruses, or by stimulating the immune system [46]. These proposed mechanisms are summarized below.

\section{Production of Viral Inhibitory Substances}

A wide range of antimicrobial compounds is produced by probiotics such as organic acids, bacteriocins, hydrogen peroxide $\left(\mathrm{H}_{2} \mathrm{O}_{2}\right)$, exopolysaccharides (EPS), and diacetyl. These agents lead to control other microbial growth [47].

\section{Organic acids}

The important and characterized antimicrobial compounds produced by $L A B$ are acetic, lactic acid, and formic acid [48]. The major end-product of sugar fermentation by LAB is lactic acid which used to inhibit microbial growth by stress resultant from the low $\mathrm{pH}$, which, in turn, makes the environment unfavorable for some pathogenic and spoilage microbial growth [49], [50]. The microbial inhibitory effects of organic acids are mainly caused by their dissociated forms, which, by changing the environment into acidic, 
interfere with essential metabolic functions [51], [52]. The acidic $\mathrm{pH}$ has been reported inactivates human immunodeficiency virus (HIV) and herpes simplex virus 2 (HSV-2) [53], [54]. Such low pH may also participate in alleviating SARS-CoV-2 infectivity.

\section{Bacteriocins}

Bacteriocins are extracellular, low-molecularweight proteins that can inhibit the microbial growth of various pathogens with distinct bacteriostatic and bactericidal effects [47], [55]. The majority of bacteriocins are heat stable and sensitive to certain proteolytic enzymes [56]. Many bacteriocins have accordingly been characterized and purified from LAB and used for a variety of industrial and biomedical applications such as food and biopreservation technology, cancer therapy, antimicrobials, and for maintaining human health [57]. Bacteriocins of LAB have some pivotal properties that gain considerable attention, such as (a) being GRAS, (b) non-toxic, (c) protease-inactivated with a slight effect on the gut microflora, (d) can tolerate $\mathrm{pH}$ and temperature ranges, (e) having the ability to inhibit many food spoilage bacteria and food-borne pathogens, (f) having bactericidal potential, and (g) they are usually plasmid-encoded [58].

In the past two decades, bacteriocins have been reported to have antiviral properties [59]. They can bind, at the cellular level, to the cell surface receptors [60]. This, in turn, could reduce the cytopathic effects and intracellular RNA of the virus at a preincubation condition [61]. Furthermore, bacteriocins and bacteriocin-like substances can interfere with the enzymatic reactions that are important for viral infection [62]. Wachsman et al. have proven the antiviral effect of entertain, a bacteriocin, against strains of HSV-1 and HSV-2 by inhibiting late stages of replication and effect on intracellular replication of the virus. Lactobacillus delbrueckii subsp. bulgaricus 1043 bacteriocin also has a virucidal effect on influenza virus [63]. Moreover, the virucidal effect of the bacteriocin subtilosin, produced by probiotic Bacillus amyloliquefaciens has also been reported against HSV and influenza virus [40], [64]. In this context, bacteriocins produced by probiotics may also have such antiviral activities against SARS-CoV-2.

\section{Hydrogen peroxide}

$\mathrm{H}_{2} \mathrm{O}_{2}$ is a compound with high reactivity at high concentrations and quite toxic to the biological systems [65]. In addition, $\mathrm{H}_{2} \mathrm{O}_{2}$ represents a strong oxidizing agent that has been shown to damage cellular membranes, DNA, and bacterial proteins [66] and have an inhibitory or lethal effect on microorganisms, depending on certain factors including concentration, temperature, $\mathrm{pH}$, and other environmental factors [67]. LAB can produce $\mathrm{H}_{2} \mathrm{O}_{2}$ when grown in the presence of oxygen through electron-transporting by different mechanisms involving flavin [68] and because they are catalase-negative, $\mathrm{H}_{2} \mathrm{O}_{2}$ can accumulate to higher concentration [50]. The induction of stress proteins allows $L A B$ to tolerate higher concentrations than the other types of bacteria [69]. Although $\mathrm{H}_{2} \mathrm{O}_{2}$ and superoxide radical $\left(\mathrm{O}^{2-}\right)$ are strong oxidant species and can increase the reactive oxygen species that lead to oxidative stress [70], a recent study by Singh et al. has revealed that $\mathrm{H}_{2} \mathrm{O}_{2}$ production by Lactobacillus johnsonii could promote epithelial restoration during colitis [71].

In regards to antiviral activities, $\mathrm{H}_{2} \mathrm{O}_{2}$, superoxide, and hydroxyl radicals are all suspected for inactivating pathogenic viruses [72]. A previous study has also shown that $\mathrm{H}_{2} \mathrm{O}_{2}$ has a significant anti-influenza virus activity [73]. Typically, $\mathrm{H}_{2} \mathrm{O}_{2}$ from Lactobacillus has a microbicidal effect in the vagina to protect the female genital tract from microbial infection. It also showed notable activities against type-1 and type-2 HIV [72], [74].

\section{Exopolysaccharides}

Polysaccharides are polymers composed of 20 to $10^{7}$ units of monosaccharides. They range from linear to highly branched structures [75]. However, EPS are long-chain biological polysaccharides produced by microorganisms [76]. It was proven that EPS have important biological activities such as antibiofilm, antitumor, antioxidant, and immunomodulatory effects [77]. EPS from the probiotic Lactobacillus plantarum strain N4 (Lp) have been shown to have an inhibitor effect on the transmissible gastroenteritis virus [77]. Furthermore, Callahan et al. [78] reported that EPS could block HIV viral entry. Such EPS may also have a preventive or inhibitory role against SARS-CoV-2.

\section{Direct virus-probiotic interaction}

Inactivation of viruses by LAB could also occur through adsorption or trapping mechanism [46]. In this mechanism, the interaction between bacteria and viruses is a principal to exhibit the antiviral effect of probiotics [79]. Conti et al. (2009) have reported that Lactobacillus isolated from vagina have a protective effect against HSV through the adhesive ability of bacteria to reduce the absorption of the virus. Bacterial cells may directly interact with viral particles and lead to trapping them or competition for cell membrane receptors [62]. A previous study stated that the probiotics trap vesicular stomatitis virus (Indiana vesiculovirus) through interaction between Lactobacillus cells and the envelope of the virus directly [80]. Similarly, Mousavi et al. [81] reported the mechanisms for the antiviral effect of L. crispatus toward HSV-2 and concluded that these 
mechanisms include (a) formation of micro-colonies in the cell surface, cause blocking to the receptors and effect on the entry of virus into the cells and (b) trapping of viral particles by $L$. crispatus that interact directly with an envelope of the virus. Furthermore, L. gasseri inhibited HSV-2 through the trapping mechanism [82]. Furthermore, Wang et al. (2013) reported the inhibition of influenza viruses by Enterococcus faecium through direct interaction. However, such mechanisms may cease SARS-CoV-2 infection or decrease viral load which is a possible factor in the severity of the disease.

\section{Stimulation of immune system}

Lactobacilli have distinct antimicrobial and antiviral activities that play an effective regulator to the immune system [83]. Furthermore, they stimulate specific and non-specific responses, including the activation of natural killer (NK) cells, enhancement of the phagocytic activity of peripheral blood leukocytes, regulatory $T$ cells, and interleukin-10. In this regard, the stimulation of nonspecific secretory and specific antibody responses to rotavirus has been recorded [84]. Recent work by Arena et al. (2018) has proven that probiotics can exert modulatory effects of the immune system by enhancing the immune defense against viruses such as induction of interleukins, T-helper cells, macrophages, NK cells, and immunoglobulins.

Several studies have evaluated the effect of some immunobiotics against enteric viruses, respiratory viruses, and pathogenic bacteria [85]. In 2010, the administration of $L$. pentosus to mice showed antiviral potential by activation of lung NK cells and decreased allergic reaction [86]. Heat-killed Lactobacillus rhamnosus strains administration has also exhibited IFN- $\alpha$ stimulation in respiratory syncytial virus (RSV) infection and decrease a viral load in mice lungs [87]. Moreover, Kawashima et al. (2011) have demonstrated that innate and adaptive immune systems are triggered by the probiotic strain, $L$. plantarum, isolated from traditional Japanese fermented food. In addition to its strong IL-12-inducing activity and IgA-inducing activity, viable $L$. plantarum has a high digestive juice resistance, leading to improved Th1 immune response and preventative activity against influenza virus infection. Too, reduction of $\mathrm{H} 1 \mathrm{~N} 1$ infection in mice by Lactobacillus fermentum has also been documented through the same mechanisms [88], [89]. Likewise, Bifidobacterium longum showed an anti-H1N1 activity by decreasing the pro-inflammatory cytokines [90]. Finally, enhancing the immune responses using probiotics' supplementation is a well-documented point; however, it may also be an effective way to alleviate COVID-19.

\section{Probiotics and Enteric Viral Infections}

The rotavirus, norovirus, adenovirus, and astrovirus are the most common viruses that cause gastroenteritis. The preventive role of probiotics against common types of viral enteritis is discussed below:

\section{Rotavirus infection}

The rotavirus infection is commonly responsible for diarrheal disease among children under 5 years of age, particularly in developing countries. Rotavirus infection is also associated with other symptoms such as vomiting, fever, and dehydration which can lead to death [91], [92]. In 2006, the US-FDA approved two oral live vaccines (RotaTeq and Rotarix) to prevent rotavirus infection in infants [93]. However, the rates of morbidity and mortality are still high [91]. In such circumstances, probiotics may consider promising cheap and safe preventive alternatives [94] to be administered to patients.

Many researchers have studied the preventive role of certain probiotics against rotavirus, such as Bifidobacterium and Lactobacillus affirmed their role in antagonizing rotaviruses [95]. Erdoğan et al. [96] have reported that the treatment of acute rotavirus gastroenteritis with Bifidobacterium lactis B94 and oral rehydration could significantly reduce the diarrheal period in children aged from 5 months to 5 years old. Later, in 2017, Park et al. [97] reach similar results after administering $B$. longum BORI and $L$. acidophilus AD031 to infants infected with rotavirus. A more recent study has proven that specific probiotic strains such as Lactobacillus salivarius PS2, L. acidophilus NCFM, Bifidobacterium breve $\mathrm{M}-16 \mathrm{~V}$, and Lactobacillus helveticus R0052 have the ability to reduce the severity of rotavirus infection [98].

Supporting the theory that probiotics can stimulate the host's immune system, Sindhu et al. [99] have mentioned that the consumption of $L$. rhamnosus (LGG) can modulate both innate and adaptive immune system's responses by increasing levels of serum IgG during infection with rotavirus. On the other hand, Fernandez-Duarte et al. [100] suggested that $B$. adolescentis and $L$. casei could block rotavirus adherence to the MA104 cells. While, a recent study indicated that non-protein components with lowmolecular-weight derived from $B$. longum BORI act as anti-rotaviral substances [101]; however, more studies are required to specify active compound to completely elucidate the underlying mechanism of action.

\section{Noroviruses infection}

Human norovirus can also cause gastroenteritis and generally lasts for $2-3$ days and accompanied by 
vomiting, nausea, and diarrhea [102]. Infants, elderly, and immunocompromised patients are the risk groups. Although acute diarrhea is generally self-limiting and may disappear within a few days [103], [104], dehydration in toddlers and young infants remains the major risk factor.

Developing vaccines and antiviral drugs against human norovirus are still under experiments [105]. Studies indicated that probiotics might act as adsorbents for $\mathrm{P}$ particle, a nano-scale sized particle in norovirus capsid and critical for the host's immune response and receptor binding [106]. For example, Enterobacter cloacae which are a commensal bacterium could bind to human norovirus through surface histo-blood group antigen and inhibit virus infectivity when tested in pigs [107], [108]. Another study showed that P particle attachment to epithelial cells could be inhibited by the presence of L. casei BL23 and Escherichia coli Nissle 1917 [109]. Accordingly, and to avoid developing severe forms of SARS-CoV-2, enhancing a healthy diet with probiotics may represent a good strategy.

\section{Probiotics and Respiratory Viral Infections}

While many researchers have concentrated on the use of probiotics totreatorpreventintestinal infections, recent research has focused on the effectiveness of probiotics on humans against respiratory viral infections [110], which are a serious cause of morbidity and mortality around the world [111]. The causative agents of respiratory viral infections in humans are over two hundred different types of pathogenic viruses, including RSV, human rhinoviruses (common cold), human enteroviruses, influenza viruses, adenoviruses, parainfluenza viruses, and coronaviruses. Symptoms of these infections vary from mild respiratory symptoms to severe diseases [112], [113], [114], [115]. Below, evidence-based probiotics' effects against common infections are highlighted below:

\section{RSV infection}

One of the most common respiratory viruses that almost all children are infected with by the age of 2 years is RSV. The symptoms can vary from mild symptoms to severe infection of the lower respiratory tract, bronchiolitis, and pneumonia with an increasing risk of developing asthma and persistent wheezing [116], [117]. Elderly and immunocompromised individuals are most at risk to be infected with RSV [118], [119]. No RSV vaccine has been approved so far, and specific antiviral medicines against RSV are still limited. Several probiotics are therefore proposed to prevent RSV infection as prophylactic or antiviral agents. For example, Tomosada et al. (2013) have found that TLR3/RIG-I antiviral respiratory immune response is modulated by intranasal administration of two different commensal strains of L. rhamnosus (L. rhamnosus CRL1505 and L. rhamnosus CRL1506) and increased infant mice resistance to RSV in comparison with a control group. In addition, recent research has shown that the RSV titer in the lungs can be significantly reduced with no weight loss in mice after viral infection when L. gasseri (LG2055) is administered orally [41].

\section{Human rhinoviruses (HRV)}

Rhinoviruses are the leading causes of common cold in humans [120]. Severe symptoms typically include irritation, pneumonia, bronchiolitis, asthma, and chronic obstructive pulmonary disease [121]. There is currently no approved antiviral treatment or vaccine for HRV infection. However, research articles have documented that various probiotics could reduce the risk of HRV disease. In a preterm population, the incidence of HRV infection was reduced significantly during the $1^{\text {st }}$ year of life through using polydextrose and L. rhamnosus [122]. Kumpu et al. [123] found that receiving $L$. rhamnosus GG (live or heat-inactivated) decreased the incidence and severity of common cold symptoms caused by rhinoviruses. However, the dose of probiotic bacterial strains, side effects, and accurate mechanism against HRV is inadequately reported and needs further investigation [124], [125].

\section{Influenza virus infection}

Another viral agent responsible for thousands of human and animal deaths annually is the influenza virus. Influenza viruses are a group of RNA viruses, which belong to the family Orthomyxoviridae. There are four types of influenza viruses A, B, C, and D. Mainly, humans are infected with type $A$ and $B$ [126]. Influenza $A$ viruses are responsible for several pandemic outbreaks worldwide [127]. Although the vaccine is available but with new viral strains evolving rapidly and variations between circulating viruses and vaccines created, the efficiency of the influenza virus vaccine decreases [128], [129]. Therefore, the efforts rely on the use of probiotics to reinforce and improve the host's immune system against viral infection. The use of yogurt fermented by L. delbrueckii ssp. bulgaricus OLL1073R-1 (R-1) might prevent infection caused by respiratory or influenza viruses through polysaccharides secretion, which improves immune system's functions and activates the NK cells [130], [131]. In a mouse model, L. acidophilus can regulate NK T-cells and prevent influenza virus infection [132]. Furthermore, the B. bifidum's effect on improving immune response to the influenza virus in a recent study on BALB/c mice infected with lethal influenza $\mathrm{A}(\mathrm{H} 1 \mathrm{~N} 1)$ has been evaluated by Mahooti et al. 
[133]. Furthermore, findings revealed a strong induction of both humoral and cellular immunity, drop in the level of IL-6, and increased survival rate in mice receiving Bifidobacterium than those of the control group.

\section{Adenoviruses infection}

Adenoviruses represent group of Rowavirales that belong to the non-enveloped double-stranded linear DNA viruses. Adenoviruses can cause various clinical syndromes in humans in addition to keratoconjunctivitis, including gastrointestinal and urogenital infections [134]. Various antiviral drugs such as ribavirin, ganciclovir, and cidofovir have shown variable activities against severe human adenovirus infections especially in immunocompromised organ transplant recipients. However, the efficiency of these drugs is limited to the ability of the virus to develop resistant strains in addition to their side effects [135]. Therefore, it is safer to stimulate the immune system and increase resistance to adenovirus infections through probiotics and their metabolic products [136]. In-vitro MTT assay against human adenovirus type 5 was used to examine the cytotoxicity of six EPSs produced by various LAB. The results showed that EPS 26a produced by Lactobacillus $\mathrm{sp}$. have a significant antiviral activity through the formation of non-infectious virus progeny [137].

\section{Probiotics and COVID-19}

In response to the emerging threat posed by SARS-CoV-2, the WHO announced a Public Health Emergency of International Concern a pandemic on March 11, 2020. Infection with SARS-CoV-2 causes coronavirus disease 19 (COVID-19), which has been characterized by fever, respiratory, and gastrointestinal symptoms, along with other less common symptoms [138]. No vaccine or antiviral drug for SARSCoV-2 has been yet approved. However, faced with this pandemic, new answers and ways of addressing these problems are needed.

Strengthening the immune system is wellknown to be an effective and successful way for a healthy lifestyle. This, in turn, oriented attention to the pivotal role of a healthy immune system to face SARSCoV-2 infection [139]. Open literature search revealed that immune system function is largely improved by a healthy diet. Accordingly, a diversified diet with a broad nutrient profile may prevent and even reduce the vulnerability during COVID-19.

Adjuvants against COVID-19 could be healthy food choices, micronutrients, bioactive compounds, and probiotics [140]. In particular, the potential benefits of probiotics in other coronavirus strains were thoroughly documented [141]. Some probiotics may also play a positive role in the treatment of COVID-19 patients due to their antiviral activity, ability to modulate inflammation, restore gut microbiome, ready availability, generally safe, inexpensive, and easily administered [142]. There are no guidelines on strain, dose, and duration of the probiotics consuming yet. However, Lactobacillus and Bifidobacterium can be safely used in different clinical situations.

A recent study by Aanouz et al. (2020) [143] on computational and molecular dynamics obviously demonstrates the antiviral activity of plantaricins, a bacteriocin, which blocks viral entry by binding with RdRp, RBD, and ACE2 through multiple mechanistic approaches by metabolic product of $L$. plantarum. Blocking the main structural protein $S$ is critical and can be one of the best targets since it plays a key role in the life cycle of SARS-CoV-2. Moreover, Anwar et al. (2020) [144] have suggested that plantaricin metabolites may be a preventive option before the latest antiviral medication specific to COVID-19 has been discovered. Other studies are being carried out across the globe to decide whether modifying the gut microbiota through the diet will contribute to our COVID-19 care, and in recent times, Baud et al. (2020) [145] have suggested certain probiotic strains that are evidence-based and that are important in reducing the pandemic burden. Apart from boosting the immune system, specific therapeutic strategies may be advised for the prevention of cytokine storm such as the use of probiotics for patients with gastrointestinal symptoms linked to COVID-19 and those with milder systemic symptoms [146].

Different patients' responses to infection may depend onvariations in the composition of theirmicrobiota and correction with probiotics may help to minimize the need for intensive care [147]. Dhar and Mohanty (2020) have identified the potential role of intestinal microbiota in determining better immune and respiratory function in such patients [148]. Too, number of authors discussed the idea of significant positive modulation of respiratory function by probiotics/synbiotics supplementation, starting from previous studies on the close associations between gut microbiota and lung function. In general, that finding indicates that probiotics are essential and useful supplements to patients and confirm the role of our microbiota in sustaining and eventually restoring a healthy quality of life.

For better understanding, the presented knowledge must be more deeply validated before they can be implemented in standard protocols for COVID19 patients, assess also the true impact of SARSCoV-2 on gut microbiota, and also take into account the possible role of gut virobiota, which seems to have a specific role in the homeostasis of gut microbiota [149]. Moreover, interactions between SARS-CoV-2 and the gut microbiome and resident virobiota could influence the ability of this new coronavirus to infect and disseminate the intestinal cells more easily and explain how probiotics could have a COVID-19 resistance [150]. 
In addition to their benefits to humans, probiotics may also participate in certain clinical presentations related to life-threatening outcomes such as bloodstream infections [151], [152]. However, neither mortality nor adverse health complications were ascribed to the clinical use of probiotics. Furthermore, additional studies are demanded to better understand their safety, behavior in the food matrix, and their survival and colonization in the gastrointestinal tract using expressly designed in vivo models.

\section{Conclusions}

With no approved vaccine or antiviral drugs for some viral disease, including COVID-19, establishing effective means to protect humans from viral infections still a bit challenging. Of the safest, affordable, and easy to consume, agents are probiotics. Enhancing the host immune system with probiotics is widely studied. They were known with their multifunctional effects, which can act as adjunctive therapy for the prophylaxis of a large number of viral infections. Finally, research needs to progress to establish probiotic scientific guidelines for the prevention and/or treatment of COVID-19.

\section{Acknowledgments}

The authors would like to thank the deanship of the College of Science (Mustansiriyah University, Iraq) and scientific affairs' section staff (Iraqi Medical Laboratory Association's, Iraq) for their support during the present work and kind assistance. Furthermore, the great efforts and constructive comments of the reviewers to improve the original draft are highly appreciated.

\section{Authors' Contribution Statement}

All authors have equally contributed to this work and approved it before submission.

\section{References}

1. Metchnikoff E. Prolongation of Life, Optimistic Studies. New York, London: Putman's Sons; 1908.

2. Kollath W. Nutrition and the tooth system; general review with special reference to vitamins. Dtsch Zahnarztl Z
1953;8(11):Suppl 7-16.

PMid: 13068115

3. Lilly DM, Stillwell RH. Probiotics: Growth-promoting factors produced by microorganisms. Science 1965;147(3659):747-8. https://doi.org/10.1126/science.147.3659.747

PMid:14242024

4. World Health Organization. Evaluation of Certain Food Additives and Contaminants. $57^{\text {th }}$ Report of the Joint FAO/WHO Expert Committee on Food Additives. Geneva, Switzerland: Biosphere Health Organization; 2002. https://doi.org/10.1002/ food. 19910350833

5. Sharifi-Rad J, Rodrigues CF, Stojanović-Radić Z, Dimitrijević M, Aleksić A, Neffe-Skocińska K, et al. Probiotics: Versatile bioactive components in promoting human health. Medicina (Kaunas) 2020;56(9):433. https://doi.org/10.3390/medicina56090433 PMid:32867260

6. Osvath R. FDA's food advisory committee to discuss criteria for safety of probiotics. Food Chem News 2000;42:12.

7. Bhattacharyya BK. Emergence of probiotics in therapeutic applications. Int J Pharm Sci Nanotechnol 2009;2(1):383-9.

8. Jahanshahi M, Dana PM, Badehnoosh B, Asemi Z, Hallajzadeh J, Mansournia MA, et al. Anti-tumor activities of probiotics in cervical cancer. J Ovarian Res 2020;13(1):68. https://doi.org/10.1186/s13048-020-00668-x PMid:32527332

9. Kos B, Šušković J, Vuković S, Simmpraga M, Frece J, Matošić S. Adhesion and aggregation ability of probiotic strain Lactobacillus acidophilus M92. J Appl Microbiol 2003;94(6):981-7. https://doi. org/10.1046/j.1365-2672.2003.01915.x PMid:12752805

10. Aly SM, Ahmed YA, Ghareeb AA, Mohamed MF. Studies on Bacillus subtilis and Lactobacillus acidophilus, as potential probiotics, on the immune response and resistance of Tilapia nilotica (Oreochromis niloticus) to challenge infections. Fish Shellfish Immunol 2008;25(1-2):128-36. https://doi. org/10.1016/j.fsi.2008.03.013 PMid:18450477

11. Bull M, Plummer S, Marchesi J, Mahenthiralingam E. The life history of Lactobacillus acidophilus as a probiotic: A tale of revisionary taxonomy, misidentification and commercial success. FEMS Microbiol Lett 2013;349(2):77-87. https://doi. org/10.1111/1574-6968.12293

PMid:24152174

12. Andreasen AS, Larsen N, Pedersen-Skovsgaard T, Berg RM, Møller K, Svendsen KD, et al. Effects of Lactobacillus acidophilus NCFM on insulin sensitivity and the systemic inflammatory response in human subjects. Br J Nutr 2010;104(12):1831-8. https://doi.org/10.1017/s0007114510002874

PMid:20815975

13. Kim SJ, Cho SY, Kim SH, Song OJ, Shin IS, Cha DS, et al. Effect of microencapsulation on viability and other characteristics in Lactobacillus acidophilus ATCC 43121. LWT Food Sci Technol 2008;41(3):493-500. https://doi.org/10.1016/j.Iwt.2007.03.025

14. Ng EW, Yeung M, Tong PS. Effects of yogurt starter cultures on the survival of Lactobacillus acidophilus. Int J Food Microbiol 2011;145(1):169-75. https://doi.org/10.1016/j. ijfoodmicro.2010.12.006 PMid:21196060

15. Klein G, Pack A, Bonaparte C, Reuter G. Taxonomy and physiology of probiotic lactic acid bacteria. Int J Food Microbiol 1998;41(2):103-25. https://doi.org/10.1016/ s0168-1605(98)00049-x PMid:9704860

16. Phillips M, Kailasapathy $\mathrm{K}$, Tran L. Viability of commercial probiotic cultures (L. acidophilus, Bifidobacterium sp., L. casei, 
L. paracasei and L. rhamnosus) in cheddar cheese. Int J Food Microbiol 2006;108(2):276-80. https://doi.org/10.1016/j. ijfoodmicro.2005.12.009

PMid: 16478637

17. YaeshimaT, TakahashiS, Ishibashi N, Shimamura S. Identification of bifidobacteria from dairy products and evaluation of a microplate hybridization method. Int J Food Microbiol 1996;30(3):303-13. https://doi.org/10.1016/0168-1605(96)00956-7

PMid:8854183

18. Groeger D, O'Mahony L, Murphy EF, Bourke JF, Dinan TG, Kiely $\mathrm{B}$, et al. Bifidobacterium infantis 35624 modulates host inflammatory processes beyond the gut. Gut Microbes 2013;4(4):325-39. https://doi.org/10.4161/gmic.25487 PMid:23842110

19. O'Mahony D, Murphy S, Boileau T, Park J, O'Brien F, Groeger D, et al. Bifidobacterium animalis AHC7 protects against pathogeninduced NF-KB activation in vivo. BMC Immunol 2010;11(1):63. https://doi.org/10.1186/1471-2172-11-63

PMid:21176205

20. Strozzi GP, Mogna L. Quantification of folic acid in human feces after administration of Bifidobacterium probiotic strains. J Clin Gastroenterol 2008;42(Suppl 3 Pt 2):S179-84. https://doi. org $/ 10.1097 / \mathrm{mcg} .0 \mathrm{~b} 013 \mathrm{e} 31818087 \mathrm{~d} 8$

PMid:18685499

21. Quigley EM. Bifidobacterium longum. In: The Microbiota in Gastrointestinal Pathophysiology. Amsterdam, Netherlands: Elsevier; 2017. p. 139-41. https://doi.org/10.1016/ b978-0-12-804024-9.00016-1

22. Tanner SA, Chassard C, Zihler Berner A, Lacroix C. Synergistic effects of Bifidobacterium thermophilum RBL67 and selected prebiotics on inhibition of Salmonella colonization in the swine proximal colon PolyFermS model. Gut Pathog 2014;6(1):44. https://doi.org/10.1186/s13099-014-0044-y

PMid:25364390

23. Nueno-Palop C, Narbad A. Probiotic assessment of Enterococcus faecalis CP58 isolated from human gut. Int $\mathrm{J}$ Food Microbiol 2011;145(2-3):390-4. https://doi.org/10.1016/j. ijfoodmicro.2010.12.029

PMid:21315470

24. Simpson KW, Rishniw M, Bellosa M, Liotta J, Lucio A, Baumgart $\mathrm{M}$, et al. Influence of Enterococcus faecium SF68 probiotic on giardiasis in dogs. J Vet Intern Med 2009;23(3):47681. https://doi.org/10.1111/j.1939-1676.2009.0283.x PMid: 19298607

25. Kimoto H, Kurisaki J, Tsuji NM, Ohmomo S, Okamoto T. Lactococci as probiotic strains: Adhesion to human enterocyte-like Caco-2 cells and tolerance to low $\mathrm{pH}$ and bile. Lett Appl Microbiol 1999;29(5):313-6. https://doi. org/10.1046/j.1365-2672.1999.00627.x PMid:10664972

26. Mao N, Cubillos-Ruiz A, Cameron DE, Collins JJ. Probiotic strains detect and suppress cholera in mice. Sci Transl Med 2018;10(445):eaao2586. https://doi.org/10.1126/scitransImed. aao2586

PMid:29899022

27. Daba H, Pandian S, Gosselin JF, Simard RE, Huang J, Lacroix C. Detection and activity of a bacteriocin produced by Leuconostoc mesenteroides. Appl Environ Microbiol 1991;57(12):3450-5. https://doi.org/10.1128/aem.57.12.3450-3455.1991

PMid:1785922

28. Barbosa J, Borges S, Teixeira P. Pediococcus acidilactici as a potential probiotic to be used in food industry. Int J Food Sci Technol 2015;50(5):1151-7. https://doi.org/10.1111/ijfs.12768

29. Huang HY, Huang SY, Chen PY, King VA, Lin YP, Tsen JH. Basic characteristics of Sporolactobacillus inulinus BCRC 14647 for potential probiotic properties. Curr Microbiol 2007;54(5):396404. https://doi.org/10.1007/s00284-006-0496-5

PMid:17387552

30. Uriot O, Denis S, Junjua M, Roussel Y, Dary-Mourot A, BlanquetDiot S. Streptococcus thermophilus: From yogurt starter to a new promising probiotic candidate? J Funct Foods 2017;37:7489. https://doi.org/10.1016/j.jf.2017.07.038

31. Duc LH, Hong HA, Barbosa TM, Henriques AO, Cutting SM. Characterization of Bacillus probiotics available for human use. Appl Environ Microbiol 2004;70(4):2161-71. https://doi. org/10.1128/aem.70.4.2161-2171.2004

PMid:15066809

32. Hong HA, Huang JM, Khaneja R, Hiep LV, Urdaci MC, Cutting SM. The safety of Bacillus subtilis and Bacillus indicus as food probiotics. J Appl Microbiol 2008;105(2):510-20. https:// doi.org/10.1111/j.1365-2672.2008.03773.x

PMid: 18312567

33. Altenhoefer A, Oswald S, Sonnenborn U, Enders C, Schulze J, Hacker J, et al. The probiotic Escherichia coli strain Nissle 1917 interferes with invasion of human intestinal epithelial cells by different enteroinvasive bacterial pathogens. FEMS Immunol Med Microbiol 2004;40(3):223-9. https://doi.org/10.1016/ s0928-8244(03)00368-7

PMid:15039098

34. Hwang IY, Koh E, Wong A, March JC, Bentley WE, Lee YS, et al. Engineered probiotic Escherichia coli can eliminate and prevent Pseudomonas aeruginosa gut infection in animal models. Nat Commun 2017;8(1):15028. https://doi.org/10.1038/ ncomms 15028

PMid:28398304

35. Cousin FJ, Jouan-Lanhouet $\mathrm{S}$, Théret N, Brenner C, Jouan E, Le Moigne-Muller G, et al. The probiotic Propionibacterium freudenreichii as a new adjuvant for TRAIL-based therapy in colorectal cancer. Oncotarget 2016;7(6):7161-78. https://doi. org/10.18632/oncotarget.6881

PMid:26771233

36. Pontier-Bres R, Prodon F, Munro P, Rampal P, Lemichez E, Peyron JF, et al. Modification of Salmonella typhimurium motility by the probiotic yeast strain Saccharomyces boulardii. PLoS One 2012;7(3):e33796. https://doi.org/10.1371/journal. pone.0033796

PMid:22442723

37. Hatoum R, Labrie S, Fliss I. Antimicrobial and probiotic properties of yeasts: From fundamental to novel applications. Front Microbiol 2012;3:421. https://doi.org/10.3389/fmicb.2012.00421 PMid:23267352

38. Ang LY, Too HK, Tan EL, Chow TK, Shek PC, Tham E, et al Antiviral activity of Lactobacillus reuteri protectis against coxsackievirus a and enterovirus 71 infection in human skeletal muscle and colon cell lines. Virol J 2016;13(1):111. https://doi. org/10.1186/s12985-016-0633-0

PMid:27341804

39. Galán NN, Rubiano JC, Reyes FA, Duarte KP, Cárdenas SP, Fernandez MF. In vitro antiviral activity of Lactobacillus casei and Bifidobacterium adolescentis against rotavirus infection monitored by NSP 4 protein production. J Appl Microbiol 2016;120(4):1041-51. https://doi.org/10.1111/jam.13069 PMid:26801008

40. Starosila D, Rybalko S, Varbanetz L, Ivanskaya N, Sorokulova I. Anti-influenza activity of a Bacillus subtilis probiotic strain. Antimicrob Agents Chemother 2017;61(7):e00539-17. https:// doi.org/10.1128/aac.00539-17 PMid:28416546

41. Eguchi K, Fujitani N, Nakagawa H, Miyazaki T. Prevention of respiratory syncytial virus infection with probiotic lactic 
acid bacterium Lactobacillus gasseri SBT2055. Sci Rep 2019;9(1):4812. https://doi.org/10.1038/s41598-019-39602-7 PMid:30886158

42. Gorbalenya AE, Baker SC, Baric RS, Groot RJ De, Gulyaeva AA, Haagmans BL, et al. The species severe acute respiratory syndrome-related coronavirus: classifying 2019-nCoV and naming it SARS-CoV-2. Nat Microbiol. 2020;5(4):536-44.

43. Li F. Structure, function, and evolution of coronavirus spike proteins. Annu Rev Virol 2016;3(1):237-61. https://doi.org/10.2 $174 / 1871530320666200427112902$ PMid:27578435

44. Zhu N, Zhang D, Wang W, Li X, Yang B, Song J, et al. A novel coronavirus from patients with pneumonia in China, 2019. N Engl J Med 2020;382(8):727-33.

PMid:31978945

45. Magrone T, Magrone M, Jirillo E. Focus on receptors for coronaviruses with special reference to angiotensin-converting enzyme 2 as a potential drug target a perspective. Endocr Metab Immune Disord Drug Targets 2020;20(6):807-11. https:// doi.org/10.2174/1871530320666200427112902 PMid:32338224

46. Al Kassaa I, Hober D, Hamze M, Chihib NE, Drider D. Antiviral potential of lactic acid bacteria and their bacteriocins. Probiotics Antimicrob Proteins 2014;6(3-4):177-85. https://doi. org/10.1007/s12602-014-9162-6

PMid:24880436

47. Prabhurajeshwar C, Chandrakanth K. Evaluation of antimicrobial properties and their substances against pathogenic bacteria in-vitro by probiotic lactobacilli strains isolated from commercial yoghurt. Clin Nutr Exp 2019;23:97-115. https://doi.org/10.1016/j. yclnex.2018.10.001

48. Lin TH, Pan TM. Characterization of an antimicrobial substance produced by Lactobacillus plantarum NTU 102. J Microbiol Immunol Infect 2019;52(3):409-17. https://doi.org/10.1016/j. jmii.2017.08.003

PMid:28863970

49. Abbasiliasi S, Tan JS, Ibrahim TA, Bashokouh F, Ramakrishnan NR, Mustafa $\mathrm{S}$, et al. Fermentation factors influencing the production of bacteriocins by lactic acid bacteria: A review. RSC Adv 2017;7(47):29395-420. https://doi.org/10.1039/c6ra24579j

50. Šušković J, Kos B, Beganović J, Pavunc AL, Habjanič K, Matoć S. Antimicrobial activity the most important property of probiotic and starter lactic acid bacteria. Food Technol Biotechnol 2010;48(3):296-307.

51. El-khawas K, Hassaan $\mathrm{H}$. Control of food poisoning bacteria during manufacturing of acid cheese using some organic acids. Assiut Vet Med J 2015;145:40-6.

52. Lorca GL, de Valdez GF. In: Ljungh Å, Wadström T, editors. Lactobacillus Molecular Biology: From Genomics to Probiotics. Norfolk, United Kingdom: Caister Academic Press; 2009. p. 115-37.

53. Martin LS, McDougal JS, Loskoski SL. Disinfection and inactivation of the human T lymphotropic virus Type III/ lymphadenopathy-associated virus. J InfectDis 1985;152(2):4003. https://doi.org/10.1128/aem.53.4.708-709.1987 PMid:2993438

54. Tuyama AC, Cheshenko N, Carlucci MJ, Li J, Goldberg CL, Waller DP, et al. ACIDFORM inactivates herpes simplex virus and prevents genital herpes in a mouse model: Optimal candidate for microbicide combinations. J Infect Dis 2006;194(6):795-803. https://doi.org/10.1086/506948

PMid:16941346

55. Digaitiene A, Hansen ÅS, Juodeikiene G, Eidukonyte D, Josephsen J. Lactic acid bacteria isolated from rye sourdoughs produce bacteriocin-like inhibitory substances active against
Bacillus subtilis and fungi. J Appl Microbiol 2012;112(4):732-42. https://doi.org/10.1111/j.1365-2672.2012.05249 PMid:22313683

56. Ge J, Sun Y, Xin X, Wang Y, Ping W. Purification and partial characterization of a novel bacteriocin synthesized by Lactobacillus paracasei HD1-7 isolated from Chinese sauerkraut juice. Sci Rep 2016;6(1):19366. https://doi.org/10.1038/ srep19366

PMid:26763314

57. Yang SC, Lin CH, Sung CT, Fang JY. Antibacterial activities of bacteriocins: Application in foods and pharmaceuticals. Front Microbiol 2014;5:241. https://doi.org/10.3389/ fmicb.2014.00683] PMid:24904554

58. Yusuf MA. Lactic acid bacteria bacteriocin producer: A mini review. IOSR J Pharm 2013;3(4):44-50.

59. Arena MP, Silvain A, Normanno G, Grieco F, Drider D, Spano G, et al. Use of Lactobacillus plantarum strains as a bio-control strategy against food-borne pathogenic microorganisms. Front Microbiol 2016;7:464. https://doi.org/10.3389/fmicb.2016.00464 PMid:27148172

60. Caramia G, Silvi S. Probiotics: From the ancient wisdom to the actual therapeutical and nutraceutical perspective. In: Probiotic Bacteria and Enteric Infections. Dordrecht: Springer Netherlands; 2011. p. 3-37. https://doi.org/10.1007/978-94-007-0386-5_1

61. Wachsman MB, Castilla V, De Ruiz Holgado AP, De Torres RA, Sesma F, Coto CE. Enterocin CRL35 inhibits late stages of HSV-1 and HSV-2 replication in vitro. Antiviral Res 2003;58(1):17-24. https://doi.org/10.1016/s0166-3542(02)00099-2 PMid:12719003

62. Arena MP, Elmastour F, Sane F, Drider D, Fiocco D, Spano G, et al. Inhibition of coxsackievirus B4 by Lactobacillus plantarum. Microbiol Res 2018;210:59-64. https://doi.org/10.1016/j. micres.2018.03.008

PMid:29625659

63. Serkedjieva J, Danova S, Ivanova I. Antiinfluenza virus activity of a bacteriocin produced by Lactobacillus delbrueckii. Appl Biochem Biotechnol 2000;88(1-3):285-98. https://doi. org/10.1385/abab:88:1-3:285

64. Torres NI, Noll KS, Xu S, Li J, Huang Q, Sinko PJ, et al. Safety, formulation and in vitro antiviral activity of the antimicrobial peptide subtilosin against herpes simplex virus Type 1 . Probiotics Antimicrob Proteins 2013;5(1):26-35. https://doi. org/10.1007/s12602-012-9123-x PMid:23637711

65. Lobo V, Patil A, Phatak A, Chandra N. Free radicals, antioxidants and functional foods: Impact on human health. Pharmacogn Rev 2010;4(8):118-26. https://doi.org/10.4103/0973-7847.70902 PMid:22228951

66. Martin H, Maris P. Synergism between hydrogen peroxide and seventeen acids against six bacterial strains. J Appl Microbiol 2012;113(3):578-90. https://doi. org/10.1111/j.1365-2672.2012.05364.x PMid:22716768

67. Baez A, Shiloach J. Effect of elevated oxygen concentration on bacteria, yeasts, and cells propagated for production of biological compounds. Microb Cell Fact 2014;13(1):181. https:// doi.org/10.1186/s12934-014-0181-5

PMid:25547171

68. Hertzberger R, Arents J, Dekker HL, Pridmore RD, Gysler C, Kleerebezem $\mathrm{M}$, et al. $\mathrm{H}_{2} \mathrm{O}_{2}$ Production in species of the Lactobacillus acidophilus group: A central role for a novel $\mathrm{NADH}$-dependent flavin reductase. Appl Environ Microbiol 2014;80(7):2229-39. https://doi.org/10.1128/aem.04272-13

69. Serata M, Kiwaki M, lino T. Functional analysis of a novel 
hydrogen peroxide resistance gene in Lactobacillus casei strain Shirota. Microbiology 2016;162(11):1885-94. https://doi. org/10.1099/mic.0.000379

PMid:27692041

70. Nita M, Grzybowski A. The role of the reactive oxygen species and oxidative stress in the pathomechanism of the agerelated ocular diseases and other pathologies of the anterior and posterior eye segments in adults. Oxid Med Cell Longev 2016;2016:3164734. https://doi.org/10.1155/2016/3164734 PMid:26881021

71. Singh AK, Hertzberger RY, Knaus UG. Hydrogen peroxide production by lactobacilli promotes epithelial restitution during colitis. Redox Biol 2018;16:11-20. https://doi.org/10.1016/j. redox.2018.02.003 PMid:29471162

72. Newcomb WW, Brown JC. Internal catalase protects herpes simplex virus from inactivation by hydrogen peroxide. J Virol 2012;86(21):11931-4. https://doi.org/10.1128/jvi.01349-12 PMid:22915822

73. Patel U, Gingerich A, Widman L, Sarr D, Tripp RA, Rada B. Susceptibility of influenza viruses to hypothiocyanite and hypoiodite produced by lactoperoxidase in a cell-free system. PLoS One 2018;13(7):e0199167. https://doi.org/10.1371/ journal.pone. 0199167 PMid:30044776

74. Conti C, Malacrino C, Mastromarino P. Inhibition of herpes simplex virus Type 2 by vaginal lactobacilli. J Physiol Pharmacol 2009;60 Suppl 6:19-26.

PMid:20224147

75. Richards MR, Lowary TL. Chemistry and biology of galactofuranose-containing polysaccharides. Chembiochem 2009;10(12):1920-38. https://doi.org/10.1002/cbic.200900208 PMid:19591187

76. Ye S, Liu F, Wang J, Wang H, Zhang M. Antioxidant activities of an exopolysaccharide isolated and purified from marine Pseudomonas PF-6. Carbohydr Polym 2012;87(1):764-770. https://doi.org/10.1016/j.carbpol.2011.08.057

77. Yang Y, Song H, Wang L, Dong W, Yang Z, Yuan P, et al. Antiviral effects of a probiotic metabolic mroducts against transmissible gastroenteritis coronavirus. J Probiotics Health 2017;5(3):184. https://doi.org/10.4172/2329-8901.1000184

78. Callahan LN, Phelan M, Mallinson M, Norcross MA. Dextran sulfate blocks antibody binding to the principal neutralizing domain of human immunodeficiency virus Type 1 without interfering with gp120-CD4 interactions. J Virol 1991;65(3):154350. https://doi.org/10.1128/jvi.65.3.1543-1550.1991 PMid:1995952

79. Wang Z, Chai W, Burwinkel M, Twardziok S, Wrede P, Palissa C, et al. Inhibitory influence of Enterococcus faecium on the propagation of swine influenza a virus in vitro. PLoS One 2013;8(1):e53043. https://doi.org/10.1371/journal. pone. 0053043 PMid:23308134

80. Botić T, Danø T, Weingartl H, Cencič A. A novel eukaryotic cell culture model to study antiviral activity of potential probiotic bacteria. Int J Food Microbiol 2007;115(2):227-34. https://doi. org/10.1016/j.ijfoodmicro.2006.10.044 PMid:17261339

81. Mousavi E, Makvandi M, Teimoori A, Ataei A, Ghafari S, Samarbaf-Zadeh A. Antiviral effects of Lactobacillus crispatus against HSV-2 in mammalian cell lines. J Chinese Med Assoc 2018;81(3):262-7. https://doi.org/10.1016/j.jcma.2017.07.010 PMid:29037754

82. Al Kassaa I, Hober D, Hamze M, Caloone D, Dewilde A, Chihib $\mathrm{N}$, et al. Vaginal Lactobacillus gasseri CMUL57 can inhibit herpes simplex Type 2 but not coxsackievirus B4E2. Arch Microbiol 2015;197(5):657-64. https://doi.org/10.1007/ s00203-015-1101-8

\section{PMid:25752765}

83. Kawashima T, Hayashi K, Kosaka A, Kawashima M, Igarashi $\mathrm{T}$, Tsutsui $\mathrm{H}$, et al. Lactobacillus plantarum strain $\mathrm{YU}$ from fermented foods activates Th1 and protective immune responses. Int Immunopharmacol 2011;11(12):2017-24. https:// doi.org/10.1016/j.intimp.2011.08.013

PMid:21893216

84. Gagnon M, Zihler A, Chassard C, Lacroix C. Ecology of probiotics and enteric protection. In: Probiotic Bacteria and Enteric Infections. Dordrecht: Springer Netherlands; 2011. p. 65-85. https://doi.org/10.1007/978-94-007-0386-5_3

85. Hemaiswarya S, Raja R, Ravikumar R, Carvalho IS. Mechanism of action of probiotics. Braz Arch Biol Technol 2013;56(1):113-9. https://doi.org/10.1590/s1516-89132013000100015

86. Izumo T, Maekawa T, Ida M, Noguchi A, Kitagawa Y, Shibata H, et al. Effect of intranasal administration of Lactobacillus pentosus S-PT84 on influenza virus infection in mice. Int Immunopharmacol 2010;10(9):1101-6. https://doi.org/10.1016/j. intimp.2010.06.012

PMid:20601181

87. Tomosada Y, Chiba E, Zelaya H, Takahashi T, Tsukida K, Kitazawa $\mathrm{H}$, et al. Nasally administered Lactobacillus rhamnosus strains differentially modulate respiratory antiviral immune responses and induce protection against respiratory syncytial virus infection. BMC Immunol 2013;14(1):40. https:// doi.org/10.1186/1471-2172-14-40

PMid:23947615

88. Yeo JM, Lee HJ, Kim JW, Lee JB, Park SY, Choi IS, et al Lactobacillus fermentum CJL-112 protects mice against influenza virus infection by activating T-helper 1 and eliciting a protective immune response. Int Immunopharmacol 2014;18(1):50-4. https://doi.org/10.1016/j.intimp.2013.10.020 PMid:24201084

89. Youn HN, Lee DH, Lee YN, Park JK, Yuk SS, Yang SY, et al. Intranasal administration of live Lactobacillus species facilitates protection against influenza virus infection in mice. Antiviral Res 2012;93(1):138-43. https://doi.org/10.1016/j. antiviral.2011.11.004

PMid:22120759

90. Iwabuchi N, Xiao JZ, Yaeshima T, Iwatsuki K. Oral administration of Bifidobacterium longum ameliorates influenza virus infection in mice. Biol Pharm Bull 2011;34(8):1352-5. https://doi. org/10.1248/bpb.34.1352

PMid:21804232

91. Crawford SE, Ramani S, Tate JE, Parashar UD, Svensson L, Hagbom $M$, et al. Rotavirus infection. Nat Rev Dis Prim 2017;3(1):17083

PMid:29119972

92. Guarino A, Dupont C, Gorelov AV, Gottrand F, Lee JK, Lin Z, et al. The management of acute diarrhea in children in developed and developing areas: From evidence base to clinical practice. Expert Opin Pharmacother 2012;13(1):17-26. https://doi.org/10. 1517/14656566.2011.634800 PMid:22106840

93. Patel MM, Haber P, Baggs J, Zuber P, Bines JE, Parashar UD. Intussusception and rotavirus vaccination: $A$ review of the available evidence. Expert Rev Vaccines 2009;8(11):1555-64. https://doi.org/10.1586/erv.09.106 PMid:19863248

94. Yang Y, Pei J, Qin Z, Wei L. Efficacy of probiotics to prevent and/or alleviate childhood rotavirus infections. J Funct Foods 2019;52:90-9. https://doi.org/10.1016/j.jf.2018.10.036 
95. Vlasova AN, Kandasamy S, Chattha KS, Rajashekara G, Saif LJ. Comparison of probiotic lactobacilli and bifidobacteria effects, immune responses and rotavirus vaccines and infection in different host species. Vet Immunol Immunopathol 2016;172:72-84. https://doi.org/10.1016/j.vetimm.2016.01.003 PMid:26809484

96. Erdoğan Ö, Tanyeri B, Torun E, Gönüllü E, Arslan H, Erenberk $U$, et al. The comparition of the efficacy of two different probiotics in rotavirus gastroenteritis in children. J Trop Med 2012;2012:787240. https://doi.org/10.1155/2012/787240 PMid:22778754

97. Park M, Kwon B, Ku S, Ji G. The efficacy of Bifidobacterium longum BORI and Lactobacillus acidophilus AD031 probiotic treatment in infants with rotavirus infection. Nutrients 2017;9(8):887. https://doi.org/10.3390/nu9080887 PMid:28813007

98. Azagra-Boronat I, Massot-Cladera M, Knipping K, Garssen J, Ben Amor K, Knol J, et al. Strain-specific probiotic properties of bifidobacteria and lactobacilli for the prevention of diarrhea caused by rotavirus in a preclinical model. Nutrients 2020;12(2):498. https://doi.org/10.3390/nu12020498 PMid:32075234

99. Sindhu KN, Sowmyanarayanan TV, Paul A, Babji S, Ajjampur SS, Priyadarshini $\mathrm{S}$, et al. Immune response and intestinal permeability in children with acute gastroenteritis treated with Lactobacillus rhamnosus GG: A randomized, double-blind, placebo-controlled trial. Clin Infect Dis 2014;58(8):1107-15. https://doi.org/10.1093/cid/ciu065

PMid:24501384

100. Fernandez-Duarte KP, Olaya-Galán NN, Salas-Cárdenas SP, Lopez-Rozo J, Gutierrez-Fernandez MF. Bifidobacterium adolescentis (DSM 20083) and Lactobacillus casei (Lafti L26DSL): Probiotics able to block the in vitro adherence of rotavirus in MA104 cells. Probiotics Antimicrob Proteins 2018;10(1):5663. https://doi.org/10.1007/s12602-017-9277-7 PMid:28432676

101. Han YO, Jeong Y, You HJ, Ku S, Ji GE, Park MS. The antirotaviral activity of low molecular weight and non-proteinaceous substance from Bifidobacterium longum BORI cell extract. Microorganisms 2019;7(4):108. https://doi.org/10.3390/ microorganisms 7040108

PMid:31018530

102. Lopman BA, Reacher MH, Vipond IB, Sarangi J, Brown DW. Clinical manifestation of norovirus gastroenteritis in health care settings. Clin Infect Dis 2004;39(3):318-24. https://doi. org/10.1086/421948

PMid:15306997

103. Green KY. Norovirus infection in immunocompromised hosts. Clin Microbiol Infect 2014;20(8):717-23.

PMid:25040790

104. Murata T, Katsushima N, Mizuta K, Muraki $\mathrm{Y}$, Hongo $\mathrm{S}$, Matsuzaki Y. Prolonged norovirus shedding in infants. Pediatr Infect Dis J 2007;26(1):46-9. https://doi.org/10.1097/01. inf.0000247102.04997.e0 PMid:17195705

105. Kocher J, Yuan L. Norovirus vaccines and potential antinorovirus drugs: Recent advances and future perspectives. Future Virol 2015;10(7):899-913. https://doi.org/10.2217/fvl.15.57 PMid:26568768

106. Chen YL, Chang PJ, Huang CT. Small P particles formed by the Taiwan-nativenorovirusPdomainoverexpressedin Komagataella pastoris. Appl Microbiol Biotechnol 2018;102(22):9707-18. https://doi.org/10.1007/s00253-018-9331-8

PMid:30187100

107. Miura T, Sano D, Suenaga A, Yoshimura T, Fuzawa M,
Nakagomi T, et al. Histo-blood group antigen-like substances of human enteric bacteria as specific adsorbents for human noroviruses. J Virol 2013;87(17):9441-51. https://doi. org/10.1128/jvi.01060-13

PMid:23804639

108. Lei S, Samuel H, Twitchell E, Bui T, Ramesh A, Wen K, et al. Enterobacter cloacae inhibits human norovirus infectivity in gnotobiotic pigs. Sci Rep 2016;6(1):25017. https://doi. org/10.1038/srep25017

\section{PMid:27113278}

109. Rubio-del-Campo A, Coll-Marqués JM, Yebra MJ, Buesa J, Pérez-Martínez G, Monedero V, et al. Noroviral P-particles as an in vitro model to assess the interactions of noroviruses with probiotics. PLoS One 2014;9(2):e89586. https://doi. org/10.1371/journal.pone.0089586 PMid:24586892

110. Hao Q, Dong BR, Wu T. Probiotics for preventing acute upper respiratory tract infections. Cochrane Database Syst Rev 2015;9:CD006895. https://doi.org/10.1002/14651858. cd006895.pub3

PMid:21901706

111. Fonkwo PN. Pricing infectious disease. EMBO Rep 2008;9(Suppl 1):S13-7.

\section{PMid: 18578017}

112. Nichols WG, Campbell AJ, Boeckh M. Respiratory viruses other than influenza virus: Impact and therapeutic advances. Clin Microbiol Rev 2008;21(2):274-90. https://doi.org/10.1128/ cmr.00045-07

PMid: 18400797

113. Robinson CM, Seto D, Jones MS, Dyer DW, Chodosh J. Molecular evolution of human species D adenoviruses. Infect Genet Evol 2011;11(6):1208-17. https://doi.org/10.1016/j. meegid.2011.04.031

PMid:21570490

114. Langley GF, Anderson LJ. Epidemiology and prevention of respiratory syncytial virus infections among infants and young children. Pediatr Infect Dis J 2011;30(6):510-7. https://doi. org/10.1097/inf.0b013e3182184ae7

PMid:21487331

115. Tapparel C, Siegrist F, Petty TJ, Kaiser L. Picornavirus and enterovirus diversity with associated human diseases. Infect Genet Evol 2013;14:282-93. https://doi.org/10.1016/j. meegid.2012.10.016

PMid:23201849

116. Hall CB, Weinberg GA, Iwane MK, Blumkin AK, Edwards KM, Staat MA, et al. The burden of respiratory syncytial virus infection in young children. N Engl J Med 2009;360(6):588-98. https://doi.org/10.1056/nejmoa0804877

PMid:19196675

117. Henderson J, Hilliard TN, Sherriff A, Stalker D, AI Shammari N, Thomas HM. Hospitalization for RSV bronchiolitis before 12 months of age and subsequent asthma, atopy and wheeze: A longitudinal birth cohort study. Pediatr Allergy Immunol 2005;16(5):386-92. https://doi. org/10.1111/j.1399-3038.2005.00298.x

PMid: 16101930

118. Higgins D, Trujillo C, Keech C. Advances in RSV vaccine research and development a global agenda. Vaccine 2016;34(26):2870-5. https://doi.org/10.1016/j.vaccine.2016.03.109

PMid:27105562

119. Openshaw PJ, Chiu C, Culley FJ, Johansson C. Protective and harmful immunity to RSV infection. Annu Rev Immunol 2017;35(1):501-32. https://doi.org/10.1146/ annurev-immunol-051116-052206 
PMid:28226227

120. Iwane MK, Prill MM, Lu X, Miller EK, Edwards KM, Hall CB et al. Human rhinovirus species associated with hospitalizations for acute respiratory illness in young US children. J Infect Dis 2011;204(11):1702-10. https://doi.org/10.1093/infdis/jir634 PMid:22013207

121. Esneau C, Bartlett N, Bochkov YA. Rhinovirus structure, replication, and classification. In: Rhinovirus Infections. Amsterdam, Netherlands: Elsevier; 2019. p. 1-23. https://doi. org/10.1016/b978-0-12-816417-4.00001-9

122. Luoto R, Ruuskanen O, Waris M, Kalliomäki M, Salminen S, Isolauri $\mathrm{E}$. Prebiotic and probiotic supplementation prevents rhinovirus infections in preterm infants: A randomized, placebocontrolled trial. J Allergy Clin Immunol 2014;133(2):405-13. https://doi.org/10.1016/j.jaci.2013.08.020

PMid:24131826

123. Kumpu M, Kekkonen RA, Korpela R, Tynkkynen S, Järvenpää S, Kautiainen $\mathrm{H}$, et al. Effect of live and inactivated Lactobacillus rhamnosus GG on experimentally induced rhinovirus colds: Randomised, double blind, placebo-controlled pilot trial. Benef Microbes 2015;6(5):631-9. https://doi.org/10.3920/ bm2014.0164

PMid:26322544

124. Esposito S, Rigante D, Principi N. Do children's upper respiratory tract infections benefit from probiotics? BMC Infect Dis 2014;14(1):194. https://doi.org/10.1186/1471-2334-14-194 PMid:24720809

125. Lehtoranta L, Pitkäranta A, Korpela R. Probiotics in respiratory virus infections. Eur J Clin Microbiol Infect Dis 2014;33(8):1289302. https://doi.org/10.1007/s10096-014-2086-y PMid:24638909

126. Howley PM, Knipe DM. Fields Virology: Emerging Viruses. Philadelphia, Pennsylvania, PA: Lippincott Williams and Wilkins; 2020.

127. Koutsakos M, Nguyen TH, Barclay WS, Kedzierska K. Knowns and unknowns of influenza $B$ viruses. Future Microbiol 2016;11(1):119-35. https://doi.org/10.2217/fmb.15.120 PMid:26684590

128. Hayden FG. Pandemic influenza. Pediatr Infect Dis J 2004;23(11 Suppl):S262-9.

PMid: 15577582

129. Verity EE, Camuglia S, Agius CT, Ong C, Shaw R, Barr I, et al. Rapid generation of pandemic influenza virus vaccine candidate strains using synthetic DNA. Influenza Other Respi Viruses 2012;6(2):101-9. https://doi. org/10.1111/j.1750-2659.2011.00273.x

PMid:21771285

130. Makino S, Sato A, Goto A, Nakamura M, Ogawa M, Chiba Y, et al. Enhanced natural killer cell activation by exopolysaccharides derived from yogurt fermented with Lactobacillus delbrueckil ssp. bulgaricus OLL1073R-1. J Dairy Sci 2016;99(2):915-23. https://doi.org/10.3168/jds.2015-10376

PMid:26686726

131. Nagai T, Makino S, Ikegami $S$, Itoh $H$, Yamada $H$. Effects of oral administration of yogurt fermented with Lactobacillus delbrueckii ssp. bulgaricus OLL1073R-1 and its exopolysaccharides against influenza virus infection in mice. Int Immunopharmacol 2011;11(12):2246-50. https://doi. org/10.1016/j.intimp.2011.09.012

PMid:21986509

132. Goto H, Sagitani A, Ashida N, Kato S, Hirota T, Shinoda T, et al. Anti-influenza virus effects of both live and non-live Lactobacillus acidophilus L-92 accompanied by the activation of innate immunity. Br J Nutr 2013;110(10):1810-8. https://doi. org/10.1017/s0007114513001104

\section{PMid:23594927}

133. Mahooti M, Abdolalipour E, Salehzadeh A, Mohebbi SR, Gorji A, Ghaemi A. Immunomodulatory and prophylactic effects of Bifidobacterium bifidum probiotic strain on influenza infection in mice. World J Microbiol Biotechnol 2019;35(6):91. https://doi. org/10.1007/s11274-019-2667-0

PMid:31161259

134. Robinson CM, Singh G, Lee JY, Dehghan S, Rajaiya J, Liu EB, et al. Molecular evolution of human adenoviruses. Sci Rep 2013;3(1):1812

PMid:23657240

135. Waye MM, Sing CW. Anti-viral drugs for human adenoviruses. Pharmaceuticals 2010;3(10):3343-54. https://doi.org/10.3390/ ph3103343

136. Ryan PM, Ross RP, Fitzgerald GF, Caplice NM, Stanton C. Sugar-coated: Exopolysaccharide producing lactic acid bacteria for food and human health applications. Food Funct 2015;6(3):679-93. https://doi.org/10.1039/c4fo00529e PMid:25580594

137. BiliavskaL, Pankivska Y, Povnitsa O, Zagorodnya S. Antivira activity of exopolysaccharides produced by lactic acid bacteria of the genera Pediococcus, Leuconostoc and Lactobacillus against human adenovirus Type 5. Medicina (B Aires) 2019;55(9):519. https://doi.org/10.3390/medicina55090519 PMid:31443536

138. Cheung KS, Hung IF, Chan PP, Lung KC, Tso E, Liu R, et al. Gastrointestinal manifestations of SARS-CoV-2 infection and virus load in fecal samples from a Hong Kong cohort: Systematic review and meta-analysis. Gastroenterology 2020;159(1):81-95. https://doi.org/10.1053/j.gastro.2020.03.065

PMid:32251668

139. Arshad MS, Khan U, Sadiq A, Khalid W, Hussain M, Yasmeen A, et al. Coronavirus disease (COVID-19) and immunity booster green foods: A mini review. Food Sci Nutr 2020;8(8):3971-6. https://doi.org/10.1002/fsn3.1719

PMid:32837716

140. de Araújo Morais AH, de Souza Aquino J, da Silva-Maia JK, de Lima Vale SH, Maciel BL, Passos TS. Nutritional status, diet and viral respiratory infections: Perspectives for severe acute respiratory syndrome coronavirus 2 . Br J Nutr 2020;1:1-12. https://doi.org/10.1017/s0007114520003311 PMid:32843118

141. Chai W, Burwinkel M, Wang Z, Palissa C, Esch B, Twardziok S, et al. Antiviral effects of a probiotic Enterococcus faecium strain against transmissible gastroenteritis coronavirus. Arch Virol 2013;158(4):799-807. https://doi.org/10.1007/ s00705-012-1543-0

PMid:23188495

142. Angurana SK, Bansal A. Probiotics and COVID-19: Think about the link. Br J Nutr 2020;1:1-26. https://doi.org/10.1017/ s000711452000361x PMid:32921328

143. Aanouz I, Belhassan A, El-Khatabi K, Lakhlifi T, El-Idrissi M, Bouachrine M. Moroccan medicinal plants as inhibitors against SARS-CoV-2 main protease: Computational investigations. J Biomol Struct Dyn 2020;1:1-9. https://doi.org/10.1080/0739110 2.2020.1758790 PMid:32306860

144. Anwar F, Altayb HN, Al-Abbasi FA, Al-Malki AL, Kamal MA, Kumar V. Antiviral effects of probiotic metabolites on COVID-19. J Biomol Struct Dyn 2020;1:1-10. https://doi.org/10.1080/07391 102.2020.1775123

PMid:32475223

145. Baud D, Agri VD, Gibson GR, Reid G, Giannoni E. Using probiotics to flatten the curve of coronavirus disease 
COVID-2019 pandemic. Front Public Health 2020;8:186. https:// doi.org/10.3389/fpubh.2020.00186

PMid:32574290

146. Infusino F, Marazzato M, Mancone M, Fedele F, Mastroianni CM, Severino $\mathrm{P}$, et al. Diet supplementation, probiotics, and nutraceuticals in SARS-CoV-2 infection: A scoping review. Nutrients 2020;12(6):1718. https://doi.org/10.3390/nu12061718 PMid:32521760

147. Inchingolo F, Dipalma G, Cirulli N, Cantore S, Saini RS, Altini V, et al. Microbiological results of improvement in periodontal condition by administration of oral probiotics. J Biol Regul Homeost Agents 2018;32(5):1323-8.

PMid:30334433

148. Dhar D, Mohanty A. Gut microbiota and Covid-19- possible link and implications. Virus Res 2020;285:198018. https://doi. org/10.1016/j.virusres.2020.198018

PMid:32430279

149. Henrot C, Kuksin M. The intestinal virobiota, a new component in the interactions between the microbiota and the immune system. Med Sci (Paris) 2019;35(6-7):578-580. doi: 10.1051/ medsci/2019113.

150. Santacroce L. Letter in response to the article "enhancing immunity in viral infections, with special emphasis on COVID-19: A review" (Jayawardena et al.). Diabetes Metab Syndr Clin Res Rev 2020;14(5):927. https://doi.org/10.1016/j.dsx.2020.06.009 PMid:32585601

151. Pillai A, Tan J, Paquette V, Panczuk J. Does probiotic bacteremia in premature infants impact clinically relevant outcomes? A case report and updated review of literature. Clin Nutr 2020;39(4):255-9. https://doi.org/10.1016/j. clnesp.2020.05.020

152. Ventoulis I, Sarmourli T, Amoiridou P, Mantzana P, Exindari M, Gioula G, et al. Bloodstream infection by Saccharomyces cerevisiae in two COVID-19 patients after receiving supplementation of Saccharomyces in the ICU. J Fungi 2020;6(3):98. https://doi.org/10.3390/jof6030098 PMid:32630111 